\title{
EMPOWERMENT STRATEGY OF DRY-LAND FARMERS: INSIGHTS FROM INDONESIA
}

\author{
Akhmad Daerobi \\ Faculty of Economics and Business, Sebelas Maret University \\ Email: daerobi_akhmad58@yahoo.com (corresponding author) \\ Eko Suyono \\ Faculty of Economics and Business, Jenderal Soedirman University \\ Email:ekyo75@unsoed.ac.id
}

Received: February 2021; Accepted: April 2021; Available online: July 2021

\begin{abstract}
The purpose of this study is to identify the level of empowerment of dry-land farmers and develop a model of strategy for empowering them. This study was done in Wonogiri Regency, Central Java Province, Indonesia. The level of empowerment is approached descriptively, while the development of an empowerment strategy uses the Analysis Hierarchy Process (AHP) method. The results shows the level of empowerment of dry-land farmers in those area is still low indicated by the power of access to economic (credit, market information, and technology) and non-economic (lobbying and stakeholders) where each value is less than $50 \%$ based on the results of the Focus Group Discussion (FGD) and indepth interviews with keypersons. The empowerment strategy can be carried out by developing production, capital procurement, production technology assistance, and improvement of dry land agroecosystems.
\end{abstract}

Keywords: dry-land farmers; empowerment strategy; FGD; AHP.

\begin{abstract}
Abstrak
Tujuan penelitian ini adalah untuk mengidentifikasi tingkat pemberdayaan petani lahan kering dan mengembangkan model strategi pemberdayaan mereka. Penelitian ini dilakukan di Kabupaten Wonogiri, Provinsi Jawa Tengah, Indonesia. Tingkat pemberdayaan dilakukan dengan pendekatan deskriptif, sedangkan pengembangan strategi pemberdayaan menggunakan metode Analysis Hierarchy Process (AHP). Hasil penelitian menunjukkan tingkat pemberdayaan petani lahan kering di wilayah tersebut masih rendah yang ditunjukkan oleh kekuatan akses ekonomi (kredit, informasi pasar, dan teknologi) dan non ekonomi (lobbying dan stakeholders) dimana masing-masing nilainya kurang dari 50\% berdasarkan hasil Focus Group Discussion (FGD) dan wawancara mendalam dengan keypersons. Strategi pemberdayaan dapat dilakukan melalui pengembangan produksi, pengadaan modal, pendampingan teknologi produksi, dan peningkatan agroekosistem lahan kering.
\end{abstract}

Kata Kunci: petani lahan kering; strategi pemberdayaan; FGD; AHP.

How to Cite: Daerobi, A., \& Suyono, E. (2021). Empowerment Strategy of Dry-land Farmers: Insights from Indonesia. Media Ekonomi dan Manajemen, 36(2), 107-123. doi: http://dx.doi.org/ 10.24856/mem.v36i2.2001. 


\section{INTRODUCTION}

Indonesia since November 17, 2012 replaced Law Number 7 of 1996 with Law Number 18 of 2012 where the aspects of food sovereignty and independence are included as philosophical foundations. Food sovereignty is the right of the state and nation to independently determine food policies that guarantee the right to food for the people and that provide the right for the community to determine a food system that is in line with the potential of local resources. One of the problems in realizing food sovereignty in Indonesia is that food is always identified with rice, even though the notion of food includes many kinds, such as corn, vegetables, meat, eggs, cassava, soybeans, and fish. However, in its development the rural community is very much dependent on rice (i.e., rice mentality). According to Usman (2004) the rice mentality is actually not accidental and is suddenly not a personal problem (a matter of taste). Rice mentality actually grows and develops together with national agricultural development policy choices that have been focused on meeting rice needs from long generation. This can be seen from the jargon that developed since the early 1960s is self-sufficiency in rice rather than self-sufficiency in food. Therefore, most of the funds and resources have been allocated to programs such as intensification, irrigation networks, and rice field printing.

Food sovereignty that is too dependent on a commodity such as rice will pose a risk that household and national food needs will be fragile. In term of consumption, it has narrowed the spectrum of commodity choices that could otherwise be used for food. Moreover, in term of production, it is also vulnerable because the availability of water for irrigation has been reduced significantly, the rate of conversion of paddy fields to non-paddy fields is very difficult to control, and the ability to expand paddy fields (new construction) is very limited because investment costs are increasingly expensive, budgets are very limited, and land is technically-socioeconomically feasible to be used as rice fields is decreasing (Sumaryanto, 2009).

Opportunities for developing dry landbased food agriculture are still widely open, although not all dry-land is suitable for agriculture. Of the total dry-land area available, most of it is in the low-lands and is suitable for agricultural cultivation of food-producing agriculture such as upland rice, corn, soybeans, and peanuts. Abdulrachman, et al. (2007) reported that out of the total dry-land area of 148 million hectares (ha), which is suitable for agricultural cultivation is only around 76.22 million ha (52\%), mostly in the lowlands (70.71 million ha or 93\%) and the rest is in the highlands, in the lowlands, flat to undulating land (slope <15\%) suitable for food crop agriculture covers 23.26 million ha, while in sloping land is 15-30\%, more suitable for annual crops (47.45 million ha). In the highlands, land suitable for food crops is only around 2.07 million ha, and for annual crops 3.44 million ha.

On the other hand, the existence of this vast and potential dry-land has not been utilized optimally for the fulfillment of the needs and welfare of rural communities. The trend, the existence of dry land has been marginalized and biased by agricultural development programs that are too focused on irrigated land. Economically, dry land commodities have not been able to provide price guarantees and a decent living to most of the main actors, i.e., farmers. Concentrations of food insecurity and poverty are mostly in rural dry-land households which is caused by relatively less natural carrying capacity, uneven socio-economic infrastructure and institutions that have not yet reached local communities, the relatively low quality of human resources, etc. According to Darsono (2012), 60 percent of poor people in Indonesia are in dry-land villages.

The helplessness of farmers makes it dry-land farmers are always in a weak 
position, even not infrequently being exploited by other economic actors who have a stronger position because they control more assets. This is because they strive and struggle alone with existing capabilities. In fact, it is not uncommon for unfair competition among peasants. In essence, the helplessness of farmers is not only due to weak control of capital (resource assets), but also because of weak and malfunctioning institutions.

In Indonesia, government attention to empowerment programs began in the 1970s until now, both by departments and between departments, such as the Joint Business Group (KUBE) in 1988 and the People's Welfare Savings/Credit Program (Takesra/Kukesra) in 1995. The program later became an inspiration for the implementation of the Inpres Desa Tertinggal (IDT) programs, the District Development Project (Proyek Pengembangan Kecamatan/PPK) in 1998 and many more such as the government program Direct Cash Assistance (Bantuan Langsung TunailBLT), cheap rice (beras miskin/raskin), and so on. In its development, there is empowerment based program labeled the National Community Empowerment Program (Program Nasional Pemberdayaan Masyarakat/ PNPM) in which 21 ministries/institutions were involved. In 2009 the PNPM project reached almost 5.720 sub-districts in Indonesia.

Various research results that examine the implementation of these community empowerment programs, report the success and also the failure of these programs (Indraningsih, et al., 2015; Syukri, et al., 2014; Muchtar, 2007; Mulder, 2008). However, a serious problem is that the farming community still does not feel the ownership of these empowerment programs, so that many programs are only the lifetime of the project and end without significant impact on people's lives. Various criticisms were addressed to the coercive empowerment program.
Development programs are increasingly difficult to reach smallholder farmers in large numbers due to lack of appreciation of local initiatives (Anantanyu, 2011); not prioritizing participation and dialogue, and the weak ability of government officials (Amien, 2005). Moreover, The organizational structure was built first, but not followed by the development of its cultural aspects.

Mardikato (2012) observed that the practice of implementing community empowerment is often far from the concept. Empowerment is becoming more "deceptive" where efforts to develop community independence are actually more likely to preserve community dependence on various forms of aid, soft loans, revolving capital, and so on. More ironically, not a few community empowerment programs are used as fields of manipulation and corruption. According to Bunch (1991) the problem of agricultural development in developing countries is not solely due to the unpreparedness of farmers to accept innovation, but caused by the inability of agricultural development program planners to adapt these programs to the conditions of farmers who are "clients" of these programs. This condition, according to Dorward \& Kydd (2004), is a picture of low level of equilibrium traps that cause poverty in many rural areas in developing countries.

Diamond (2005) in his analysis of learning failures of various nations, states that the failure is due to the weakness of decision makers understanding the existence of complex social conditions (complex societies) with these characteristics: centralized decisions, high information flow, high coordination, instruction by formal authorities, and centralization of resources. The existence of complex societies, according to Diamond (2005), almost always ends in failure. Therefore, several contemporary studies of powerlessness such as Mc. Arthur and Sachs (2001) and Sachs et al. 
(2002) emphasize the importance of geographical approaches in empowerment programs. According to them, the geographical position is crucial to the development of a society's progress or setbacks. Studies in several other regions also show the importance of geographical factors in mapping poverty problems.

Based on above discussions, the purpose of this study is: firstly, to identify the level of empowerment of dry-land farmers and, secondly, to develop a strategy model for empowering dry-land farmers by using Wonogiri Region, Central Java Province, Indonesia as the research area. The selection of this region as research area due to it is a real picture of the condition of the dry-land region where the economic structure is very dependent on the agricultural sector, especially the food crops sub-sector. Dry-land food crops are the base sector in almost districts in this region where various dry-land crop commodities such as cassava and maize become regional superior commodities. However, at the level of on farming still faced with low productivity (harvest frequency, varieties), farmers are still reluctant to take care of the plants optimally, post-harvest technology has not been developed, and high water levels are still found in crop yields; all of which are a reflection of the powerlessness of farmers. Moreover, in term of the per capita Gross Regional Domestic Product (GRDP), this region is the lowest compared to the per capita GRDP in the are of former residency of Surakarta. Likewise, the percentage of poverty rates in this region is relatively high, higher than the percentage at the provincial level (Badan Pusat Statistik Provinsi Jawa Tengah, 2014).

\section{LITERATURE REVIEW}

\section{The Concept of Empowerment}

The essence of the empowerment concept according to Page and Czuba (1999) is power, namely the power to change. Based on this context, empowerment has the same meaning with dynamism or dynamics, which generic meaning means movement or strength, ability, power, reason or ways to overcome something, or achieve goals. A society where most of its members are physically and mentally healthy and educated and strong and innovative, of course has high empowerment. However, in addition to the physical values above, there are also intrinsic values in society which are also a source of empowerment, such as family values, mutual cooperation, struggle, and diversity. Community empowerment is the elements that enable a community to survive, and in a dynamic sense develop themselves and achieve progress. This community empowerment is the source of what is called political insight at the national level as national resilience.

Adimihardja in Setiawan (2008) defines the empowerment of farmers as a power to make decisions and determine actions to be taken related to the farmers themselves, including reducing the effects of personal and social barriers in taking action. Short-term empowerment is usually realized because of stimuli, for example farm credit/kredit usaha tani (KUT) funding assistance, efforts to improve economic position, and so on. Long-term empowerment is an empowerment in the form of the will, ability, and readiness of the community to be independent in developing, fulfilling, and solving the problems they face. Meanwhile, Tanziha (2011) used four indicators of the level of empowerment of farmers, namely the ability to plan, implement, evaluate, and overcome farming problems.

Susilowati, et al. (2004) and Susilowati and Kirana (2008) in their research on developing a model of coastal community empowerment, looking at community empowerment from economic and non-economic aspects. Economic aspects include business access, market information access, and technology access, meanwhile, non-economic aspects include access to lobbying, business decisions, breaking boundaries, and the role of 
stakeholders. This concept was referred to several privious studies such as Sudantoko (2010) in his research of the small scale batik industry in Central Java, Anisah (2007) in her research on fish processors in Tegal City; and Widayati (2008) in her research on the management of fish auction sites in the Pantura area of Central Java.

Conceptually, the empowerment approach cannot be separated from the paradigm of social development that shifted the development approach in the 1960s, which was driven more by the myth of growth. The concept of empowerment emerges with two major premises: failure and hope (Friedmann, 1992). The failure in question is the failure of economic development models in tackling the problem of poverty and the environment that is sustainable. While expectations, show the existence of development alternatives that incorporate democratic values, gender equality, and economic growth adequately. These failures and hopes are not a measure of social science, but rather a reflection of normative and moral values that are very real at the individual and community level. Thus, community empowerment is essentially a collective value of individual empowerment.

Empowerment is not an instant process. There needs to be a stage where each stage occurs the process of development towards improvement. As a process, empowerment has 5 stages, namely: (1). information dissemination; (2) consulting; (3). idea gathering/sharing; (4). delegating; and (5) empowerment (Jhonson and Redmon, 1998; in Susilowati et al., 2004).

\section{The Concept of Powerlessness}

The concept of powerlessness is those who are weak and do not have the power, strength or ability to access productive resources or people who are marginalized in development
(Sumodiningrat, 2000). Powerlessness and poverty are two conditions that are very closely interrelated and influence each other. Sumodiningrat (2005) states that poor people are generally characterized by several things as follows, firstly the powerlessness or inability to meet basic needs such as food and nutrition, clothing, shelter, education and health (basic need deprivation). Second, powerlessness and inability to carry out productive business activities (unproductiveness). Third, the inability to reach social and economic resources (inaccecibilty). Fourth, powerlessness and inability to determine their own destiny and always receive discriminatory treatment, have feelings of fear and suspicion, and apathy. Fifth, free yourself from the mentality and culture of the poor and always feel to have dignity and low self-esteem (no freedom for poor).

Internal factors that cause people to be helpless include economic incapacity (poverty), feelings of inferiority and helplessness, not being aware that they are poor, dependent habits, and limited knowledge and skills. While external factors include limited information, access to resources, injustice, and the existence of power that does not favor the poor. All that makes them have no bargaining position (Midgley, 1986). Even though poverty alleviation efforts have been made and have succeeded in reducing poverty, the quality of life of the poor is still low. They are still enveloped by various conditions that are interrelated to one another, such as weak exchange yields in production, low productivity, low quality human resources, low access to development outcomes, lack of capital, weak bargaining position, and weak organization.

\section{Empowerment Strategies}

According to Reksohadiprodjo, et.al (1992) there are three definitions of strategy. First, strategy is a plan that unites, puts together all parts of the company. Second, the strategy is a comprehensive 
plan, covering all major aspects of the company. Third, strategy is an integrated plan, combining one plan with another. Moreover, Mintzberg (1995) defined strategy into five meanings namely plan, ploy, pattern, position, and perspective. He argued that in addition to being a guide for action towards the future, strategy is also a pattern of steps taken in the past. Besides strategy is a tool to create a position in the context of its environment (strategy is positioning), and to obtain and maintain that position, companies need fundamental collective behavior in doing everything (strategy is perspective). Porter (2014) states that strategy is the most important tool to achieve competitive advantage.

Based on several definitions of the strategy above, it can be concluded that the strategy is a plan or way to anticipate through the integration of activities in order to have competitiveness as an effort to achieve the desired goals. Within the scope of farmer empowerment, a strategy can be interpreted as a unified plan of farmer community activities by empowering existing facilities, in order to compete with the parties associated with it. Empowerment strategies are needed because there are outsiders who tend to dominate or dominate farmers, or because the environment does not always offer opportunities but also threats.

The strategy carried out by the government is actualized into the program to increase farmers' output and income, hhile the input is dry land. The process of solving is done by the method of dialogue, discovery and development. Furthermore, the model of farmer empowerment is carried out through a process of counseling, training and piloting (fostered business). Success indicators of empowerment can be measured through the empowerment of dryland farmers.

\section{RESEARCH METHODS}

The study was conducted on food crop farming in the dry land in Wonogiri Regency in March-July 2015. The selection of the research area was based on the consideration that the Wonogiri Regency is one of the districts that has a relatively large area of dry-land. Central Java BPS data 2012 shows that the percentage of dry-land in Wonogiri region is more than $80 \%$. Likewise, dry-land farming is spread in all sub-districts in the district (Badan Pisat Statistik Jawa Tengah, 2016).

The population for this research is directed at the dominant dry-land farming in Central Java, in Wonogiri Region. The population size is 604,632 farmers spread in 25 districts. The sample of dry-land farmers was taken by the quota multistage sampling method (Susilowati et al., 2004) of 150 respondents of dry-land farmers in three selected districts in Wonogiri Region. Quota sampling technique is a sampling method based on a certain quota. This sampling technique was chosen because the sample population in the three selected districts has the same characteristics as the macro, namely Wonogiri Region where the land is mostly used as upland agriculture (soybeans, corn, cassava, beans, tubers, and upland rice).

The level of empowerment of farming is seen from access to economic and non-economic forces. Access to economic power can be seen from access to credit, market access, and technology access. Therefore: high level of empowerment, if $\geq 50 \%$ of respondents have the ability to access credit for their business activities. Market access is measured by the ability of respondents to buy inputs and sell output in the market. The level of empowerment is high, if $\geq$ $50 \%$ of respondents have the ability to buy inputs and sell output in the market. Technology access is measured by the respondent's ability to access technology by making changes to the improvement of technology. High level of empowerment, if $\geq 50 \%$ of respondents have the ability to access technology by making changes to technological improvements. 


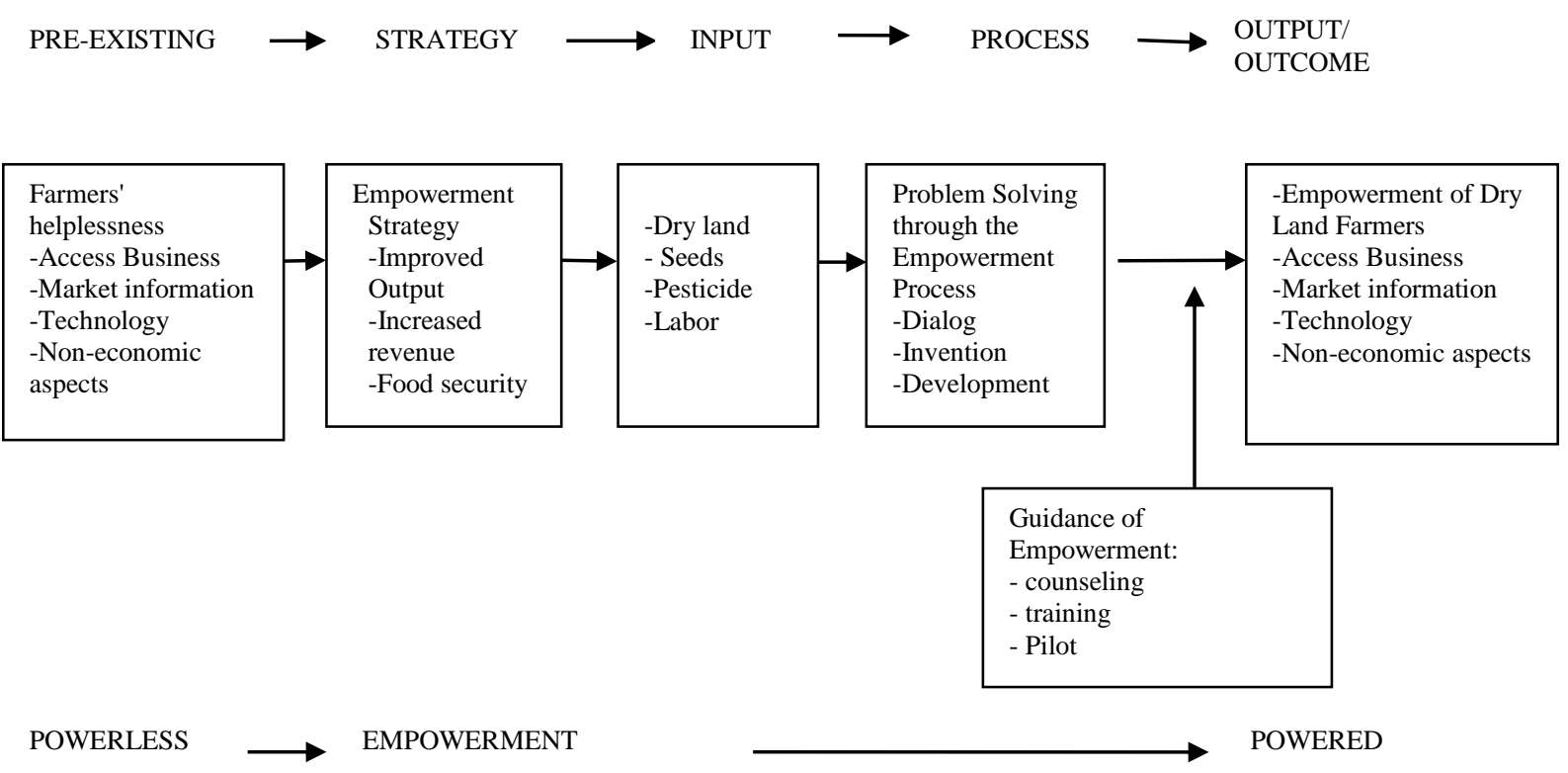

Figure 1. Empowerment Strategy of Dryland Farmers

Source: Hikmat (2001) and Susilowati et al. (2004)

Access to non-economic forces is seen from political and stakeholder access. Political access is measured by the ability of respondents to lobby and present themselves or their groups. The level of empowerment is high if the respondent has the ability of $\geq 50 \%$ in lobbying with decision makers related to his farm. Stakeholder access is measured by the intensity of the respondent's relationship with the stakeholder. The level of empowerment is high if $\geq 50 \%$ of respondents have an intensive relationship with stakeholders (Susilowati et al., 2004; 2005).

The empowerment strategy is carried out through several stages, namely Focus Group Discussion (FGD), in-depth interviews with keypersons, and conducting Analysis Hierarchy Process (AHP). The FGD technique is in the form of discussions with focus groups, namely key informants to discuss specific issues in more depth. Participants in the FGD were academics, government, farmers, suppliers of production facilities, distributors of dryland farming products, and related NGOs. The aim is to obtain opinions and suggestions in the process of designing a model for empowering dry-land farming.
FGD results and in-depth interviews with keypersons determine various aspects related to the development of dry-land farming. Besides that, it can also know the priorities needed for the development of dry-land farming. To identify and determine priorities in complex decisionmaking researchers use the Analysis Hierarchy Process (AHP) technique (Saaty, 1993).

\section{RESULT AND DISCUSSION}

\section{Overview of Research Areas}

Wonogiri Regency with an area of $182,236.02$ hectares or $5.59 \%$ of the area of Central Java Province is geographically located between 7032 'and 80 15' South Latitude and between 110041 'and 1110 18' East Longitude (BT). The natural condition consists mostly of limestone rocky-mountains, especially in the southern part, including the thousand mountains range which is the Bengawan Solo spring. Wonogiri Tropical temperate, has 2 rainy and dry seasons with an average temperature of $24^{\circ}-37^{\circ} \mathrm{C}$.

Topographical conditions where most of the land is hilly in the form of limestone mountains, uneven with an 
average slope of 300, the height of the land varies considerably between sub-districts, ranging from 106 meters to more than 600 meters above sea level with very diverse soil types, namely lithosols, regosol and grumusol and their associations, and are derived from a variety of parent materials including sedimentary or volcanic rocks, so that this greatly affects the condition of existing natural resources as well as influencing the potential of artificial resources which are potential superior regions.

\section{Level of Empowerment of Dry Land Farmers}

\section{Access to Credit}

The level of empowerment of dry-land farmers in the study area was measured by several accesses, i.e., credit, market access, technology. Each access has a different measurement indicator. Table 3 shows that of the 150 respondents who claimed to have received credit only 46 farmers $(22.67 \%)$ from formal and informal financial institutions whereas those who have never received credit are far greater, namely $116(77.33 \%)$. There are various reasons why farmers cannot access credit. Some of them are afraid because they will not be able to return it, have no information about credit, do not meet the requirements requested, and far from the farmers location.

\section{Market access}

The transition from subsistence to commercial farming is often referred to as agricultural commercialization. The implications of agricultural commercialization can be seen from the market institutionalization which is very important for the sustainability of farming and food security, nutrition, related industries, and farmers' income. Market is required when farmers act as managers of farming to buy inputs and sell outputs, as well as, when farmers act as consumers. They spend their income to buy goods and services needed for their households in the market. The market provides the structure and process of determining what is produced and consumed. Barriers to market access is disturbing the standard of living of farmers. In the study area most of the respondent of farmers did not have market access as showed in Table 1 where more than $75 \%$ of farmers do not have market access. They sell their products or buy more production facilities based on their proximity to collectors.

Table 1. Empowerment of Respondents of Dryland Farmers

\begin{tabular}{|c|c|c|c|}
\hline Level of Empowerment & Explanation & Frequency & Persentage (\%) \\
\hline \multirow[t]{2}{*}{ 1. Credit access } & yes & 46 & 22.67 \\
\hline & No & 116 & 77.33 \\
\hline \multicolumn{2}{|c|}{ Total } & 150 & 100,00 \\
\hline \multirow[t]{2}{*}{ 2. Market access } & yes & 32 & 21.33 \\
\hline & No & 118 & 78.67 \\
\hline \multicolumn{2}{|c|}{ Total } & 150 & 100.00 \\
\hline \multirow[t]{2}{*}{ 3. Tecknology access } & Modern & 39 & 26.00 \\
\hline & Traditional & 111 & 74.00 \\
\hline \multicolumn{2}{|c|}{ Total } & 150 & 100.00 \\
\hline \multirow[t]{2}{*}{ 4. Lobbying access } & Yes & 37 & 24.67 \\
\hline & No & 113 & 75.33 \\
\hline \multicolumn{2}{|c|}{ Total } & 150 & 100.00 \\
\hline \multirow[t]{2}{*}{ 5. Stakeholders' access } & Yes & 63 & 42.00 \\
\hline & No & 87 & 58.00 \\
\hline \multicolumn{2}{|c|}{ Total } & 150 & 100.00 \\
\hline
\end{tabular}




\section{Access to Technology}

Access to technology in this research is related to the production process, specifically the production techniques used by respondents. Table 1 at shows that the majority of respondents $(74 \%)$ use traditional production techniques. This is in-line with the Ford Foundation (in Setiawan, 2008) which states that the adoption of advanced technology is not optimal by dry-land farmers and the limited availability of capital and infrastructure that is not as good as in the paddy fields. Moreover, Setiawan (2008) states that during the last three decades, corn production only grows around 3.9\%. Even though domestic needs grew by $4.6 \%$, the slow growth of corn production is caused by the suboptimal cultivation technology. The corn culture technology is not optimal due to the low motivation of farmers.

\section{Strategy for Empowering Dry-land Farmers}

The aim of empowering dry-land farmers is to enable and empower them from being helpless to being empowered. In general, the powerlessness of farmers is caused by two main factors that interrelate with each other, namely internal factors and external factors. Internal factors related to problems and constraints originating from within the individual, such as low motivation, lack of capital, incompetence, weak mastery of management and technology aspects, unfavorable choices, all of which are weak capacities of individual farmers. While external factors come from the environment that does not conducive hamper farmers in accessing and obtaining productive assets such as capital, land, and means of employment, education, housing, health services, security, politics, and so on.

Based on this logic, the strategy of empowering dry-land farmers applied must touch the problems faced by dry-land farmers, both internally and externally. Therefore, the strategy needs to be developed with relevant stakeholders, who directly or indirectly have an interest in the sustainability of the dry-land farmer's business. The government has an interest in making land use regulations, including promoting the welfare of farmers; the private sector has an interest in supplying and buying farmers' products; NGOs have an interest in providing advocacy; the farmer community has an interest in maintaining shared values, and academics have an interest in research, technology development, and education of the farming community.

Through FGD results, in-depth interviews with 20 relevant stakeholder keypersons in their fields, the strategy of empowering dry-land farmers can be formulated into four areas namely access to productive assets and markets, access to politics, promoting shared values, and increasing individual capacity. Furthermore, after being calculated through the AHP program with the Expert Choice 2000 software, the rsult can be seen in Figure 2.
Production aspect

Processing aspect

Individual capacity building $\quad .393$

Marketing aspect

Inconsistency $=.007$

with 0 missing judgments
.250

.243

.114

Figure 2. Development Criteria for Dryland Farmers 
Figure 2 at shows the main priorities for the strategy of empowering dry-land farmers in Wonogiri Region are the aspects of production, processing, increasing production capacity, and marketing aspects. The overall inconsistency ratio value is $0.007<0.1 \quad$ (maximum limit) which means the results of the analysis can be accepted.

The results of the overall analysis show that the priority scale of criteria and alternative management of dry-land agriculture with AHP can be seen in Figure 3 . The overall inconsistency ratio value is $0.08<0.1$ (maximum limit) which means the results of the analysis can be accepted. Based on this picture it can be seen that the three priorities in the development of dryland agriculture, namely: a) Capital Procurement (weight 0.183), b) Procurement of Production Facilities (weight 0.117), c) Investment assistance (0.113), d) Partnership (0.119), and e) Improving Agroecosystems (0.100).

\section{Empowerment Strategy for Dry Land Farmers Based on the Production Aspect}

AHP analysis results show that production aspects are the main priority in empowering dry-land farmers, capital networks and production facilities are program priorities in the effort to empower dry-land farmers in accessing productive resources, each with a weighting value of 0.187 and 0.117 . Moreover, the access to production technology has a relatively small weight of 0.016. As an effort to develop the capital network, there are various alternatives that can be done by the government and stakeholders related to capital network implementation. Firstly, develop farmers' awareness to mobilize finances on the basis of their own abilities. At the time of harvest, farmers have excess cash supply and during the planting and maintenance season, cash supply is shrinking. Thus, farmers need to manage finances appropriately. As an alternative the need for awareness for farmers to save money in financial institutions available in the village, such as savings and credit cooperatives, KUD, BRI Village Unit, and so on. The financial institution itself needs to pay close attention to when the harvest occurs. Secondly, financial institutions operating in the village both formal and informal financial institutions are strived to coordinate on the basis of a spirit of mutualism, or mutual benefit. Thirdly, the need to develop banking that focuses on agriculture, including dry-land agriculture in particular. This opportunity can be utilized by the Village Credit Board (Badan Kredit Desa/BKD), the Rural Credit Fund Institute (LDKP), Grameen Bank, etc.

The strategy of procuring means of production is intended to enable dry-land farmers to be able to purchase the required inputs. Farmers are often weak in accessing cheap and quality inputs, and weak in market information. The intended inputs are seeds, fertilizers, and pesticides. Crucial problems faced by farmers include the unavailability of short-lived varieties of vrietas, so that dry land productivity is still low and high water levels are still found in the yields. Input prices are more determined by the seller. Various strategies that can be implemented include strengthening farmer associations such as farmer groups, farmer cooperative associations, and other groups, so that farmers have a high bargaining position.

A strategy for improving dry-land ecosystems is needed, because in many cases, many farmers carry out activities that damage the preservation of land, such as burning of exhausted rice straw, slash and burn systems for land clearing, excessive use of pesticides, unbalanced fertilization, cutting down forest wood for buildings and materials burn wildly and so on. On the other hand, dry-land is sensitive to erosion, is sloped, reacts acidically, and is nutrient poor. Therefore, to achieve sustainable farming, farmers must implement land conservation, namely the 
maintenance of dry-land including planting plants or patio reinforcement grass, crop rotation, maintenance of terraces or cans, making drainage channels, and using manure.

Production technology can be seen as a long-term strategy. The challenges facing dry-land farmers are even greater. Technology is increasingly important when there is a rapid and uncertain change in prices and climate, so farmers often find it difficult to anticipate it. In some regions in Indonesia the symptoms of climate change are starting to be felt, including the dry season which lasts from year to year is getting longer, and the rainy season with a higher intensity, but the time is shorter and shifts from the usual time (Naylor et al, 2002). On the other hand, the challenges of the environment and the new economy, innovation systems are determined more by consumers (demand side) than producers (supply side); so that demands for food that is nutritious, nutritious, protein and environmentally friendly are even stronger. In such a situation, the production technology needed must be more productive, feasible, sustainable, and a strong agricultural system. The strategy needed is: firstly, take collective action to access shared information and exchange experiences. Collectively, through farmer groups, they can utilize information technology such as computers, e-mail, and the internet, which can help farmers become sustainable entrepreneurs, manage efficiently and offer more diverse services to their members. Secondly, stakeholder platforms, which are mechanisms jointly between public organizations and the private sector as well as other actors to develop trust and communication. The network in question includes various associations such as HKTI and various associations of farmers, cooperatives, traders, exporters; and others. This multistakeholder network can be utilized by dryland farmers in accessing modern technology, while at the same time fighting for their interests so that their aspiration is included in the formulation of government policies.

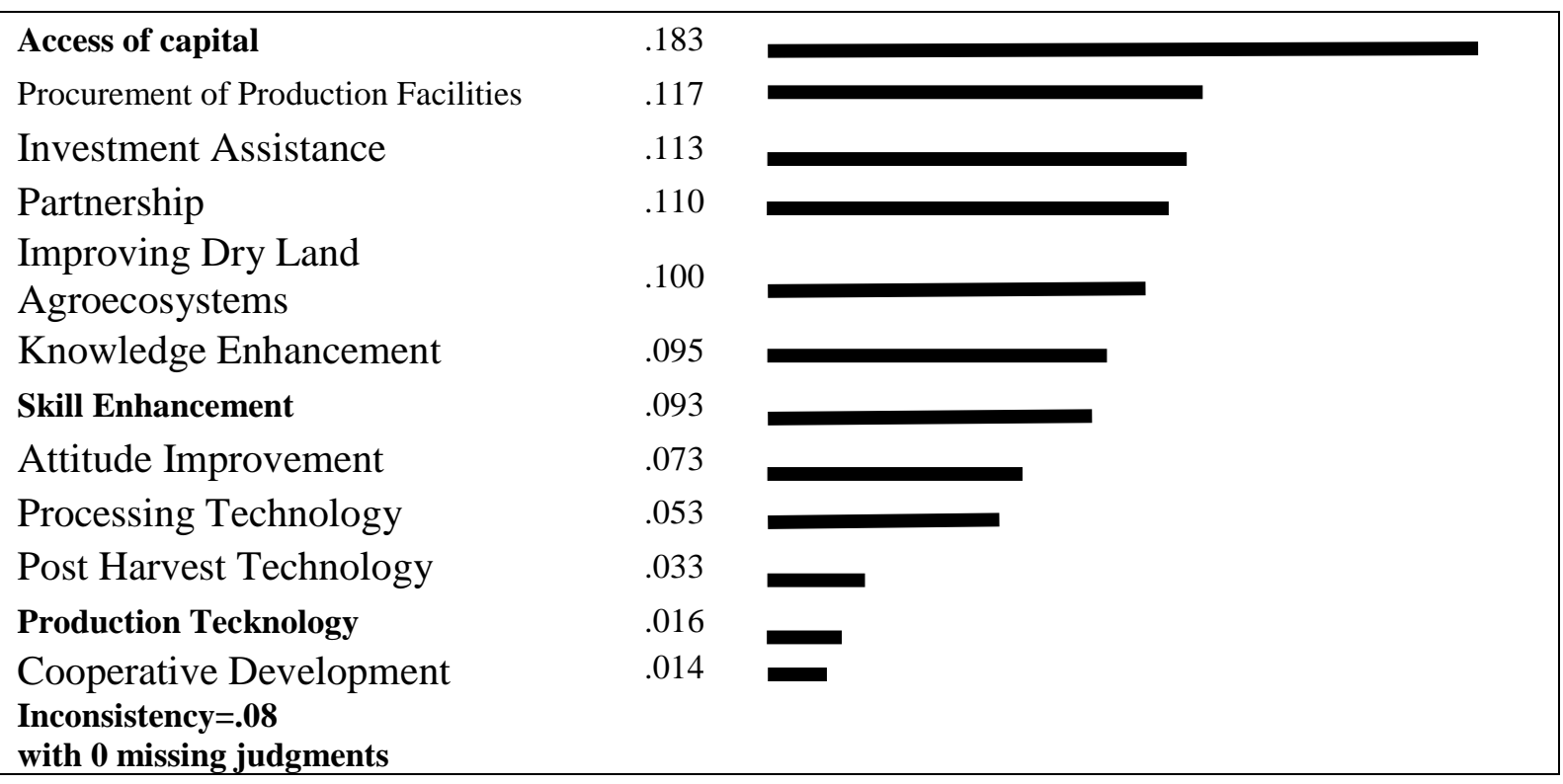

Figure 3. Priority Criteria and Alternative Development of Dry Land Farmers 


\section{Strategy for Empowerment of Dry-land Farmers Based on Processing Aspects}

The processing aspect is a postharvest activity as an integral part of agribusiness development which starts from the aspect of raw material production to the marketing of the final product. The role of processing becomes very important because it is an activity of creating added value of agricultural products. Compared to fresh products, processed products can provide relatively large added values, thus increasing farmers' income. Processed products can be used as a home industry that involves housewives from farmers.

The industrial processing strategy is intended to increase the ability of farmers to process their crops into industrial materials, as an effort to increase income. For example corn is processed into corn flour and corn starch; cassava is processed into cassava flour, cassava and cassava; and upland rice processed into rice flour. Food processing is an effort to improve the ability of farmers to process their crops into processed foods. For example, corn is processed into marning, long chips, buttersweet, sweet corn, and so on; cassava is processed into tiwul, crackers, chips, and so on; rice is processed into fried rice, apem cakes, and so on. In general, the development of processing businesses in Wonogiri Region faces obstacles mainly due to the limited facilities and infrastructure for agroindustry development, food processing technology, human resource skills, and business capital. Implementation of the strategy in the short term is to provide investment assistance such as processing equipment for home industries through farmer groups; revitalizing tools, i.e. replacing damaged equipment so that it can function again or facilitate the grinding unit.

In the long run, improvements to postharvest technology and processing technology will be necessary. This activity can be implemented through research activities, especially in the context of technological innovation and improving the quality of processed products; the formation and training of food and nutrition cadres, especially for housewives; and training on food processing and business development in the processing industry, especially for women in rural areas to process local food, using appropriate technology.

\section{Strategy for Empowerment of Dry Land Farmers Based on Aspects Marketing}

Empowerment strategy through marketing is very necessary for farmers, because often they face various problems. Firstly, the production is seasonal and simultaneous, so when the harvest is very abundant, the price is low. Secondly, the location of farm businesses that are scattered so difficult for the process of gathering production. This condition makes it difficult for collecting traders in terms of collection and transportation, so that it will increase marketing costs. This fee will be charged to farmers by suppressing farmers' products. Thirdly, the nature of agricultural products that are easily damaged, heavy and requires a lot of space, so agricultural products must be quickly sold or processed, for family needs. Likewise, in purchasing the required inputs, farmers are often weak in accessing cheap and quality inputs, and weak in market information. The strategies that can be implemented are through developing partnership patterns between farmers and output marketers and input providers. So far, the pattern of partnership between farmers in Wonogiri is still limited. Sampoerna Agro partnerships with cassava farmers in land management and marketing of cassava, but the area is still limited, so it has not affected supply, demand, and prices in the market.

In the long run, cooperatives are needed to be developed as a people's economic movement, which is a place for 
the people's economic activities around them. In this case the cooperative can develop commodity marketing activities of its members. Theoretically when there is a market failure, the role of cooperatives is needed by its members in the procurement of production facilities and marketing the products which is produced by their members. Some actions that can be taken are, firstly, cooperative management training for management and managers, related to management, seeking business opportunities, developing promotions, and so on. Secondly, creatively cooperating with various companies in the fields of procurement, processing and marketing; so that cooperatives can play a role from upstream to downstream in the member commodity agribusiness system.

\section{Strategy for Empowerment of Dry-land Farmers Based on Individual Capacity Building}

The capacity of a farmer can be interpreted as the abilities inherent in his personality, which manages agricultural resources to be able to set farm goals precisely and achieve the goals set in the right way. Naturally every farmer has an inherent capacity. The capacity of human beings will determine the actions taken. Actions have an understanding of something done or an action. Each farmer can differ from one another the level of capacity and action in managing his farm. There are various views in seeing the capacity of farmers, there are those who see the ability to take advantage of opportunities, overcome problems and maintain the sustainability of farming. In this study, farmers' capacity is seen from their skills, knowledge, and attitudes, so that efforts to empower farmers' capacity are focused on those aspects. AHP analysis results show improved attitude, increased knowledge, and skill weight is relatively low; implies that this strategy is more long-term oriented.

Attitude is a mindset of someone who can be actualized into the dynamics of his life. For most farmers in Java, including dry-land farmers in the study area, in general have a willing (rila, narima) and patient attitude. If this concept is interpreted as an attitude of absolute surrender to everything that will happen, without being accompanied by efforts to change existing conditions, then they are difficult to accept new ideas. They tend not to express their thoughts and views, are apathetic, are unwilling to express their opinions and ideas. Strategies for this kind of improvement need a relatively long time and patience for agents of change in the field, such as agricultural extension to motivate farmers to develop, participate in various extension activities, and understand that farming is a noble and very profitable job in order to improve family welfare. For this reason, the number of agricultural extension workers in Wonogiri Region needs to be increased where the current conditions show that not every village has agricultural extension workers.

The capacity of farmers to manage their farms is part of local knowledge. This knowledge developed through word of mouth oral traditions over generation, from one farmer to another, and from his own experience during farming. His experience in dealing with the successes and failures of crops, pest attacks, changing seasons, and so on enriched the knowledge of the farmers concerned. Farmers can also get farming knowledge from visual and print media, extension workers, or from the various training that is followed. The variety of knowledge possessed greatly determines the success of farmers in managing their farming. However, most farmers do not learn from various sources of knowledge, so the success of farming is relatively low. For this strategy to increase knowledge capacity, including increasing the relationship between farmers and agricultural extension workers, increasing the number of agricultural extension workers in the study area, and various good farming practices. 
With regard to farming skills related to farming, during this time farmers use traditional technology which are used for generations. Land management, seed preparation, how to plant, weeding, how to fertilize, and how to harvest, are still traditional. Likewise, post-harvest technology, such as sorting, grading, and packing, is not yet widespread by farmers. For this strategy to increase knowledge capacity, including incentivizing the relationship between farmers and agricultural extension workers, increasing the number of agricultural extension workers in the study area, adding facilities that support extension services, and various good farming practices.

Based on the explanation above, in the empowerment of dry-land farmers which includes aspects of production, processing, marketing, and individual capacity of farmers; active roles from various parties are needed. In a situation of helplessness, it is impossible for farmers to be left alone to rise up to become empowered. For this priority empowerment is based on critical short and long term.

\section{CONCLUSIONS}

The level of empowerment of farmers in the study area (i.e., Wonogiri Region, Central Java Province, Indonesia) is still low, as indicated by access to economic strength (credit, market information, technology) and non-economy (lobbying, business decisions, and stakeholder roles), each of which is less than $50 \%$. It implies the need for a strategy to improve and develop dry-land farmers. Based on the results of the FGD, in-depth interviews with Keypersons and AHP found that dry land farming needs to be developed. Empowerment can be done by considering several aspects, i.e., firstly, aspect of production is to facilitate the procurement of production facilities, procurement of capital, production technology assistance, and improvement of dry-land agroecosystems. Secondly, processing aspects by providing investment assistance, post- harvest handling technology application training, and processing technology. Thirdly, marketing aspects by developing partnerships and developing cooperatives. Fourthly, aspects of increasing individual capacity through improving attitudes, increasing knowledge, and improving farmers' skills.

The results of this study provide new insights in seeing dry-land farmers which is seen from the level of empowerment. Although dry-land farmers produce superior commodities, various indicators of economic and non-economic empowerment indicate that their level of empowerment is still low. Therefore, it needs an empowerment strategy so that they become empowered and as a result their income can be increased. The strategy of empowering dry-land farmers applied must be a holistic paradigm, namely empowering a whole and integrated with attention to spatial aspects, namely touching the problems faced by dry-land farmers both on the internal and external sides. For this, the strategy needs to be developed with relevant stakeholders who directly or indirectly have an interest in the sustainability of the dry-land farmer business. The government has an interest in making land use regulations including promoting the welfare of farmers; the private sector has an interest in supplying and buying farmers' products; NGOs have an interest in providing advocacy; the farming community has an interest in maintaining shared values, and academics have an interest in research, technology development, and education.

The strategy to develop and increase the empowerment of dry-land farmers needs to be based on four aspects, namely the aspects of production, processing, marketing, and increasing individual capacity. The strategy is actualized into various activities. Firstly, in the aspect of production, access to capital and production facilities is needed by dry-land farmers. Moreover, strategies for improving dry-land ecosystems and 
developing production technology are very relevant to be applied. Secondly, strategies based on aspects of processing. Processed products can be used as a home industry that involves housewives from farmers. Thirdly, empowerment strategies through marketing. This strategy is very necessary for farmers, because often they face various problems related to the sale of outputs and the purchase of inputs. The strategies that can be implemented include developing a partnership pattern between farmers and output marketers and input providers. Fourthly, the strategy of empowering dry-land farmers based on increasing individual capacity. The steps taken are through efforts to improve farmers 'attitudes, increase farmers' knowledge and skills. The implementation of the strategy is based on short-term and long-term priorities.

Lastly, this study has limitation where it was conducted on dry-land farmers in Wonogiri Regency, so that generalizations cannot be made in other farms. However, in a context that is not much different, such as dry-land farmers based on crops, this study contributes an important reference. Moreover, various strategies in this study have not yet been tested through applications to dry-land farmers. Therefore, the next studies could test the formulation of this strategy to palawijabased dry-land farmers. Likewise, the dynamics of dry-land farmers are very broad with various perspectives such as the agribusiness system, the agribusiness subsystem, patterns of income and expenditure, social capital, and institutions. In subsequent studies a deeper study can be carried out by incorporating these dynamics.

\section{References}

Abdurachman, A., Dariah, A., \& Mulyani, A. (2008). Strategi dan Teknologi Pengelolaan Lahan Kering Mendukung Pengadaan Pangan Nasional, Jurnal Litbang Pertanian, 27 (2), 43-49.
Anisah, R.N. (2007). Analisis Tingkat Keberdayaan Pengolah Ikan yang Berorientasi Pasar (Studi Empiris Di Kota Tegal). Tesis Program Studi Magister Manajemen Sumberdaya Pantai, Program Pascasarjana Universitas Diponegoro, Semarang.

Amien, M. (2005). Kemandirian Lokal. Gramedia Pustaka Utama, Jakarta

Anantanyu, S. (2011). Kelembagaan petani: peran dan strategi pengembangan kapasitasnya. SEPA Jurnal Sosial Ekonomi Pertanian dan Agribisnis, 7 (2), 102-109.

Badan Pusat Statistik Provinsi Jawa Tengah, (2014). Data dan Informasi Kemiskinan Jawa Tengah 20102014. Badan Pusat Statistik Provinsi Jawa Tengah. Retrived from https://jateng.bps.go.id/publication/d ownload.html.

Badan Pusat Statistik Provinsi Jawa Tengah, (2014). Statistik Pertanian Hortikultura Kemiskinan Jawa Tengah 2012-2014. Badan Pusat Statistik Provinsi Jawa Tengah. Retrived from https://jateng.bps.go.id/publication/d ownload.html

Bunch, R. (1991). Dua Tongkol Jagung: Pedoman Pengembangan Pertanian Berpangkal Pada Rakyat. Terjemahan oleh Ilya Moeliono. Yayasan Obor Indonesia. Jakarta.

Darsono, D. (2012). Faktor Utama Swasembada Pangan Tingkat Rumah Tangga Petani Lahan Kering Di Kabupaten Wonogiri Provinsi Jawa Tengah. SEPA Jurnal Sosial Ekonomi Pertanian dan Agribisnis, 9 (1), 100-116. 
Diamond, J. (2005). COLLAPSE: How Societies Choose to Fail or Survive. Penguin Books Ltd, USA.

Dorward, A. R., \& Kydd, J.G. (2004). The Malawi 2002 Food Crisis: The Rural Development Challenge. Journal of Modern Africa Studies, 42(3), 343361.

Friedmann, J. (1992). Empowerment: The Ploitics of Alternative Development, Cambridge Mass, Blackwell Publisher.

Hikmat, H (2001), Strategi Pemberdayaan Masyarakat. Humaniora Utama, Bandung.

Indraningsih, K.S., Supriadi, H., Prasetyo, B., \& Muslim, C. (2015). Analisis Kebijakan Implementasi Program Pemberdayaan Masyarakat Pedesaan. Pusat Sosial Ekonomi Dan Kebijakan Pertanian Badan Penelitian dan Pengembangan Pertanian Kementerian Pertanian. Retrived from http://pse.litbang.pertanian.go.id/ind/ pdffiles/anjak_2015_10.pdf.

Mardikanto, M. (2012). Model-model Pemberdayaan Masyarakat. UNS Press.

Mc. Arthur, J.W., \& Sachs, J.D. (2001). Institution and Geography: Comment on Acemoglu, Johnson and Robinson. NBER Working Paper Series No: w8114.

Midgley, J. (1986). Community

Participation : History, Concepts and Controversies, in James Midgley, Editor. Communnity Participation, Social Development and the State. Methuen \& $\mathrm{Co}, \mathrm{New}$ York, USA.
Mintzberg, H., Quinn, J.B., Voyer, J. (1995). The Strategy Process. Prentice-Hall, Inc, New Jersey, USA.

Muchtar, M. (2007). Pemberdayaan Masyarakat Melalui Program Pengembangan Distrik Kajian Kebijakan dan Implementasinya di Provinsi Papua, Jurnal Penelitian dan Pengembangan Kesejahteraan Sosial, 12 (2), 1-10.

Mulder, N. (2008). Reviews and Evaluations of Pro-Poor Programs in Indonesia: A Summary Overview. Working Paper No. 3, HICKLING, Jakarta, February 2008.

Naylor, R.L., Falcon, W., Wada, N., \& Rochberg, D. (2002). Using El NinoSouthern Oscillation Climate Data to Improve Food Policy Planning in Indonesia. Bulletin of Indonesian Economic Studies, 38(1): 75-91.

Page, N., \& Czuba, C.E. (1999). Empowerment: What is it?, Journal of Extension, 37 (5), 24-32.

Porter, M.E. (2014). Competitive Advantage: Creating and Sustaining Superior Performance. Simon \& Schuster, New York, USA.

Reksohadiprodjo, S., Hani,T., \& Siswanto, S. (1986). Kebijaksanaan Perusahaan, BPFE, Yogyakarta.

Saaty, T.L. (1993). Pengambilaan Keputusan Bagi Manajemen. Proses Hirarki Analitik Untuk Pengambilan Keputusan dalam situasi yang Kompleks. (Terjemahan) Seri Manajemen No. 134. PT. Pustaka Binama Pressindo, Jakarta. 
Sachs, J.D., Bajpai, N., \& Ramiah, A. (2002). Understanding Regional Economy Growth in India. Center for International Development (CID), Harvard

University.

Setiawan, I. (2008). Alternatif Pemberdayaan Bagi Peningkatan Kesejahteraan Petani Lahan Kering (Studi Literatur Petani Jagung di Jawa Barat). Jurusan Sosial Ekonomi Pertani, Fakultas Pertanian, Universitas Padjadjaran, Bandung.

Sudantoko, J. (2010). Pemberdayaan Industri Batik Skala Kecil Di Jawa Tengah (Studi Kasus di Kabupaten dan Kota Pekalongan). Disertasi Program Pascasarjana, Universitas Diponegoro, Semarang.

Sumaryanto, F.N. (2009). Diversifikasi Sebagai Salah Satu Pilar Ketahanan Pangan, Forum Penelitian Agro Ekonomi, 27 (2), 93-108.

Sumodiningrat, G. (2000). Visi dan Misi Pembangunan Pertanian Berbasis Pemberdayaan. IDEA, Yogyakarta.

Susilowati, I., Tohir, M., Waridin, W., Winarni, T., \& Sudaryono, A. (2004). Pengembangan Model Pemberdayaan Masyarakat Pesisir (Usaha Mikro, Kecil, Menengah dan Koperasi- UMKMK) dalam Mendukung Ketahanan Pangan di Kabupaten/Kota Pekalongan, JawaTengah. Laporan Penelitian Riset Unggulan Kemasyarakatan dan Kemitraan (RUKK) Tahun I, Universitas Diponegoro, Semarang.
Susilowati, I., \& Kirana, M. (2008). Pemberdayaan Masyarakat Pada Usaha Mikro Kecil Di Sektor Perikanan, Buku Ajar Berbasis Riset, Badan Penerbit Universitas Diponegoro, Semarang.

Syukri, M., Hastuti, H., Akhmadi, A., Kartawijaya, K., \& Kurniawan, A. (2014). Studi Kualitatif Proliferasi dan Integrasi Program Pemberdayaan Masyarakat di Jawa Tengah, Nusa Tenggara Barat, dan Sulawesi Selatan. Laporan Penelitian Lembaga Penelitian SMERU. Retrived from https://smeru.or.id/id/content/studikualitatif-proliferasi-dan-integrasiprogram-pemberdayaan-masyarakatdi-jawa-tengah.

Tanziha, I. (2011). Model Pemberdayaan Petani Menuju Ketahanan Pangan Keluarga. Jurnal Gizi dan Pangan, 6(1), 90-99.

Usman, S. (2004). Pembangunan dan Pemberdayaan Masyarakat, Pustaka Pelajar, Yogyakarta. 